\title{
CROP INTENSIFICATION PROJECT ACTIVITIES AND LIVELIHOOD IMPROVEMENT IN RWANDA A CASE OF MAIZE FARMERS IN MUNYAGA SECTOR, RWAMAGANA DISTRICT
}

\author{
Jean Bosco Sezirahiga ${ }^{1 *}$, Marie Claire Mukamazimpaka ${ }^{2}$, \\ ${ }^{*}$ School of social sciences, Development Studies (MDS), Mount Kenya University, Kigali, Rwanda \\ ${ }^{2}$ Mount Kenya University
}

*Corresponding Author: -

\begin{abstract}
: -
Fruit main objective of this research is to examine the impact of Crop Intensification Program activities on the improvement of livelihoods in Rwanda. Concerning the sampling technique, the methodology to be used in information collection was questionnaire and interview guide that was conducted together with observation which was helpful in interpreting results. This research was conducted at the maize farmers in four cells located in Munyaga sector totaling 99 households making up the sample of respondents which was chosen randomly from the total of 6978 maize farmers. The findings proves that there is a relationship between increased land cultivation and increased diet and food security $(p=.479$ with sig=.000) between increased land cultivation and improved health $(p=.730$ of sig=.000) between increased seeds, yield and improved household income $(p=.936$ with sig=.000) between improved household income and improved health $(p=.630$ of sig=.000) between increased diet and food security and improved health $(p=.688$ with sig=.000) because all calculated $p$-values are less than the 0.01 level of significance. Therefore, this implies that there is a relationship between predictors of crop intensification project activities and livelihood improvement of maize farmers in Munyaga Sector of Rwamagana District in Rwanda. The $R$ coefficient of 0.820 reveals that crop intensification project activities has a positive relationship on the health improvement. The coefficient of determination $.672 R$ square also indicates that crop intensification project activities explain $67.2 \%$ the variability of progressing in improved health status. Therefore, this shows that predictors of crop intensification project activities such as increased land of cultivation, improved seeds and yields affect the progress of improved health by $67.2 \%$ in CIP Munyaga Sector of Rwamagana District in Rwanda. Therefore, referring on the findings of the work the researcher is recommending local authorities to encourage farmers to join associations for crop intensification in order to enhance their livelihoods, to provide efficient management of the peasant masses to make possible means easier for maize farmers to access the most modern maize growing equipment, educate farmers in fertilizer use and integrated soil fertility and crop management and maintain an enabling market environment that encourage private sector investments. The researcher would like to recommend to improve access of information on market, price, supply availability, provide information to investors related to crop profitability, accessibility to finance, and to have considerable collaboration with sector and district agronomists in order to achieve production target. In conclusion, the findings have revealed that the livelihood of maize farmers has improved after joining crop intensification because the same results have proved a positive and significant relation between crop intensification project activities and livelihood improvement in Munyaga Sector, Rwamanaga District of Rwanda.
\end{abstract}

Keywords: - Crop Intensification Project Activities, Livelihood Improvement, Maize Farmers, Rwanda

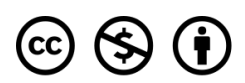




\section{INTRODUCTION}

Rwanda has consistently managed to attain an outstanding progress in the economic growth and poverty reduction efforts for a considerable duration of time. Indeed, the agricultural sector has remained the leading employers as it is depended on as the major form of daily livelihoods for a significant amount of the country's population. Besides, higher than $80 \%$ of the country's people resides in villages and holds subsistence smallscale farms averaging a land size of 0.59 ha (MINAGRI, 2011). Owing to the existing agricultural characteristics of the country, it is evident that there is need for a policy and an institutional framework documenting innovative ways to enhance agricultural production and to show the looming issues of the fast-growing population and food security.

The issue surrounding feeding the mounting population is conveniently a global challenge, but places significant threat to developing countries that are faced by severe food insecurity issues and high rates of poverty (FAO, et al., 2021). This means that investing more efforts on the agricultural sector is essential especially if issues to do with economic growth, food security, and poverty must be dealt with speed. It is in this respect that since 2007, Rwanda has taken fundamental steps to escalating small - scale agriculture through the crop intensification project, that has been accomplished by boosting agricultural productivity through the expansion of farm inputs, irrigation, and enhancing the quality of soil (Cantore, 2011).

Therefore, the Rwandan state is implementing the ways of improving livelihoods to the population of low income by promoting crop intensification project and creating agricultural cooperatives in all Rwandan Sectors (Kabandana, 2016). The increased yields provide food security and stability which in turn triggered an array of social and economic transformation. Though, studies have shown that crop intensification project activities have increased farm productivity and creation of agricultural cooperatives but they also have ignored the role of crop intensification project in improving livelihood of farmers in terms improved health, increased diet and food security and improved household income. This was the reason why, the researcher conducted this study to examine the impact of CIP activities in improving the livelihood of maize farmers in Munyaga Sector in Rwamagana District, Rwanda.

\subsection{Objectives of the study \\ 1.1.1 General objective}

The main objective of the study is to analyze the impact of crop intensification project activities on livelihood improvement with a case of maize farmers in Munyaga sector, Rwamagana District of Rwanda.

\subsubsection{Specific objectives}

(i) To assess crop intensification project activities conducted by maize farmers to increase diet and food security in Munyaga Sector, Rwanda;

(ii) To establish the effect of crop intensification project activities on improved household income of maize farmers in Munyaga Sector, Rwanda

(iii) To examine the relationship between crops intensification project activities and improved health of maize farmers in Munyaga Sector, Rwanda.

\section{Review of Literature}

\subsection{Empirical Literature}

The empirical studies have emerged to assess the causes of the poor production of African agriculture. The study suggests that African farmers face many agronomic, biophysical, institutional, socio-economic, constraints that limit the yield (Diagne et al., 2013). In relating with the constraints related to crop intensification, input intensification, explained as the use of modern practices and inputs like application of mineral fertilizers, hybrid seeds, crop protection chemicals, water and soil management practices, is the most promising approach to maintaining production growth. Despite, recent study highlights that African farmer use at low rate these inputs mainly on strategic staple crops like rice, maize, sorghum and millet (Sheahan \& Barrett, 2017).

Other studies conducted in the field of crop intensification and livelihood improvement demonstrated the space in application of modern inputs between Africa and the rest of the world show the part of the gap in the productivity of agriculture. The low rate of using the modern agriculture inputs in Africa has affected the output of the farm by causing constraints of resources, physical accessibility and incomplete market (Karlan, et al., 2014); issues of risks and uncertainty (Dercon \& Christiaensen, 2011; and Suri, 2011) and less human capital play roles and import (Conley \& Udry, 2010). Highlighting these challenges holds much potential for raising productivity, and also food security and poverty reduction that improve farmers' livelihoods.

In the studies conducted in relation to crop intensification project and livelihood improvement indicated that creativity is taken as a key driver of yield increase. Creativity in agriculture deals with adopting modern technologies and techniques like use of fertilizers, crop protection, use of chemicals, hybrid seeds and integration of soil and water management through irrigation practices to enlarge production to limit issue of food insecurity (Feder et al., 2015; and Byerlee, 2016). The growers have adopted the above technologies that increase crop productions over the short time termed as a green revolution (Pingali, 2012). However, the green revolution bypassed Sub- Saharan African countries where the crop production has remained low and widely stagnated in comparison to other places (Sheahan \& Barrett, 2017). Given the importance of agriculture in the households' livelihoods and the economy, it has become evident that addressing the issues facing African growers in increasing crop yield is crucial to promote pro-poor food security and economic development. 
The research made by Tittonell, et al. (2010), revealed that exploration of crop intensification is supportive to transitional improvement of livelihoods and orientation of market beyond sufficiency of food energy for the half distribution of households. Thus, the crop intensification increases the availability of food and household income furthermore it is analyzed through distribution of food among households rather than mean average farm household types or farm households and they also highlighted that those limited profits are potentially realized mainly by the marginally food inadequate or food adequate, rather than the most food inadequate households. Recent researches have also highlighted that mineral fertilizer needs to be complemented with other non-mineral nutrients in crop intensification, particularly on depleted or acid soil, to enhance their effectiveness (Burke, et al., 2017). Matsumoto and Yamano (2011) in Kenya, find that many growers are already using nitrogen at an agronomic optimum level, and more increases in production can only happen with complementary technologies. Furthermore, diseases, pests and weeds can inflict important damages to crop if plants aren't protected within the vegetative phase of their growth (Diagne et al., 2013). Therefore, the productivity profit in terms of return from the sole application of mineral fertilizer might never materialize, inhibiting adopting in subsequent seasons to increase farming productivity which in turn enhances household income.

A number of studies in this field of crop intensification and livelihood improvement recognize the agricultural input intensification merits; the governments in Africa have invested in project that raise the farm productivity through access to modern inputs. The agricultural input old recipe subsidies remain the main instrumental policy to use in many governments (Jayne \& Rashid, 2013). Despite, there also important reforms started to enhance markets and increase investment in infrastructure. As the outcomes of these concerted efforts over the past two decades, the use of mineral fertilizer by African farmers is improving and starts to translate into seen yield growth (Sheahan \& Barrett, 2017; and Sommer, et al., 2013). Thus, the growth of the yields has made the families of the farmers to increase their household income.

Most of the studies related to crop intensification project activities and livelihood improvement have indicated the agendas of development have put their focus on sustainability of crop intensification in agricultural project (Tittonell, 2003; and Townsend et al., 2013). The crop intensification produced food which is increase on the same land for a long period of time with keeping the integrity of the ecosystem with concerns on the maintenance of environmental resources to support the yields and lives of the people which in turn help to improve health of the people due to balance diet produce from farming (Pretty et al., 2011). The study of Knox et al., (2012) made projections on the remaining or the negative annual growth in crop yield and livestock in years preceding 2050. Researches have showed that meaningful capacity remains to close the gaps of production in cereal crops trough efforts of intensification like agricultural management and improved practices (Licker, et al. 2010, Tittonell \& Giller, 2013; and Berg, et al., 2013).

The empirical study conducted by Collier and Dercon (2014), on crop intensification and smallholder farm household in Africa demonstrated that intensification systems aim at affecting change at the basic economics of smallholder farm, the households have the capacity to access the demands of food and societal projected foods needs mainly in the areas facing the issues related to high growth of the people which increase food demands, improved health, climate change and resource degradation. The study of Valbuena et al., (2014), stated that the objectives of projecting development projects are helped to aggregate the level of household impact on crop intensification systems. The crop intensification project supports the increase of $60 \%$ in productivity of the farm by 2013 around 2.5 million households as per projections with a minimum increase of $44 \%$ earning of households in the same number of households.

The same study has also stated that sustainable crop intensification strategy is actually based on sustainability of environment and society distributes the interests from the harvest of the intensification project, households of smallholders are different in their level of poverty, household and farm characteristics, status of food security and agro-ecological context. Although intensification sustainability is the necessity for the society and environmental survival views, giving less attention the distribution of interest from crop intensification, livestock on households of smallholder. It also has other survival views where the farmers earn another angle of live that touches health of the farmer due to increased and balanced diet.

\subsection{Research Gap}

The studies conducted in this field of crop intensification project activities and livelihood improvement have indicated that crop intensification produces the more food at the same land for a long time period to support integrity of the ecosystem and environmental resources (Pretty, et al., 2011). While, other researchers have showed that important capacity stays to fill production gaps main cereal crops through intensification efforts like agricultural management and improved practices (Licker, et al., 2010, Tittonell \& Giller, 2013; and Berg, et al., 2013). Therefore, this shows that much of the studies in this field have given less attention the role of crop intensification project activities on improving the farmers' livelihoods in terms of improved households' income, increased diet and food security, improved health and savings as well as employment security and increase of sales of agricultural production.

The empirical studies carried out by Zingore et al., (2007); and Tittonell et al., (2010); Humid tropics (2012); collier and Dercon (2014), Vanlauwe et al., (2014), Morris, 2007; and Sheahan and Barrett, 2017), have only focused on the agricultural production from crop intensification not the livelihood improvement of the farmers. This shows that most of the researches conducted in this area of study related to crop intensification and livelihood improvement have given less attention the role of crop intensification project activities in assuring extension of service delivery, increasing land cultivation and production, use of improved seeds and yields and control of pest, diseases and erosion to improve livelihoods of farmers. In this in this context the researcher wants to fill the gap left out by the empirical researchers in this field and assess the role of crop intensification project activities in improving livelihoods of farmers in Rwanda with reference to Munyaga Sector farmers in Rwamagana District. 


\section{Materials and Methods}

The study used correlational research design to prove the association between crop intensification and livelihoods improvement maize farmers in Rwanda. Therefore, the selected farmers were deemed to be a good source of information than others which geared the researcher to get a sample from the Cells since they characterized by absolute farming. The study is carried out in Munyaga sector of Rwamagana district in the Eastern province of Rwanda. The target population is 6,978 households of maize farmers living in 4 cells of Munyaga sector as it's the one which used enough agricultural input for an appreciable period of time. Therefore, 99 head of households were considered as main respondents using Yemane (1967) formula. Research used the questionnaire to 95 maize farmers as respondents simply because the responses were calculated using standardized data analysis procedures and questionnaires. The main purpose of using key informants' interview to 4 exemplary maize farmers in each strata is to complement the main instrument, the questionnaire; structured interview was given to the exemplary maize farmers to enhance the quality of the primary data because they were expected to have enough information regarding crop intensification project activities and livelihood improvement compared to other farmers in their groups

The data collected by direct observation on the field and using questionnaires. Each respondent's questionnaire was coded to avoid duplication in responses, and then data were entered and synthesized using the Statistical Packages for Social Sciences (SPSS 20), that data is analyzed using qualitative and quantitative statistical procedure and methods. After data was collected, it's information were processed related to the objectives of the study that was considered and transformed into a meaningful data for easy interpretation and understanding. The correlational statistical measures were applied to assess the quantitative data and summarized and categorized in table, means, percentage and frequencies, standard deviation, correlation and regression analysis. Qualitative analytical method was also used (mainly for the data obtained through the qualitative methods) such as explanation and interpretation of various views, concepts and opinions; and be summarized, categorized and presented in suitable form.

\section{Research Findings}

4.1 The crop intensification project activities conducted by Maize farmers to increase diet and food security in Munyaga Sector, Rwanda

Table 4.1: Descriptive statistics on assessment of crop intensification project activities

\begin{tabular}{|c|c|c|c|c|c|c|c|}
\hline IP Activities & 5 & 4 & 3 & 2 & 1 & Mean & SD \\
\hline Extension services delivery & $4(4.0 \%)$ & $5(5.1 \%)$ & $20(20.2 \%)$ & $4(4.0 \%)$ & $66(66.7 \%)$ & 1.757 & 1.178 \\
\hline $\begin{array}{l}\text { hcrease land for maize } \\
\text { ultivation }\end{array}$ & $4(4.0 \%)$ & & & $10(10.1 \%)$ & $76(76.8 \%)$ & 1.494 & 1.063 \\
\hline $\begin{array}{l}\text { Improvement of seeds and } \\
\text { yields }\end{array}$ & $3(3$. & 10 & 14 & 1) & $\%)$ & 1.888 & 1.168 \\
\hline f nects & $8(8.1$ & $10(10$ & & & & 2.060 & 1.323 \\
\hline e disease & & & & & & 1.818 & 1.091 \\
\hline & & & & & & & 1.002 \\
\hline & & & & & & 1.979 & 1.124 \\
\hline d chemical & $4(4.0 \%)$ & $4(4.0 \%)$ & $15(1$ & $23(23.2 \%)$ & $53(53.5 \%)$ & 1.818 & 1.091 \\
\hline Land & $8(8$. & $0,0$. & & & & 1.757 & 1.262 \\
\hline & $21(21.2 \%)$ & $35(35.4 \%)$ & $7(7.1 \%)$ & $25(25.3 \%)$ & $11(11.1 \%)$ & 3.303 & 1.351 \\
\hline & & & & & & 1.966 & \\
\hline
\end{tabular}

Source: Primary Data, 2021

The results in Table 4.1 shows that $66(66.7 \%)$ of respondents strongly agreed that extension of delivery service is practiced in crop intensification project to improve the households' livelihoods of farmers, $76(76.8 \%)$ of respondents strongly agreed that they increase land for maize cultivation, 54 (54.5\%) of respondents strongly agreed that they improve seeds as an activity to improve livelihoods of farmers households, 49 (49.5\%) of respondents strongly agreed that they control pests as another activity to increase farmers households livelihood improvement.

The results have also indicated that $50(50.5 \%)$ of respondents strongly agreed that they control maize diseases as an activity to increase farmers households livelihood improvement, 48 (48.5\%) of respondents strongly agreed that they control erosion as an activity of farmers to enhance households livelihood improvement, 46 (46.5\%) of respondents strongly agreed that they practice irrigation as another activity to farmers to enhance household's livelihood improvement, $53(53.5 \%)$ of respondents strongly agreed that they use natural and chemical fertilizers for the sake of farmers household's livelihood improvement.

The results continue to demonstrate that $51(51.5 \%)$ of respondents strongly agreed that they do watering for the sake of farmers household's livelihood improvement, 63 (63.6\%) of respondents strongly agreed that they consolidated land for the sake of farmers household's livelihood improvement, 65 (65.7\%) of respondents strongly agreed that they control droughts for the sake of farmers household's livelihood improvement. The results have also indicated that the general mean is 1.966 which tends towards strongly agree implying that the activities conducted by farmers in crop intensification project has improved livelihoods of Maize farmers in Munyaga Sector in Rwanda. 
The results reveal that crop intensification project activities conducted by Maize farmers to increase diet and food security in Munyaga Sector, Rwanda. To compare the results of this research with that of Townsend et al., (2013), who stated that sustainable intensification of agricultural yield has become predominant theme in the development agendas and it has helped to improve the livelihood of rural households. Thus, the results are supported by the results of Townsend et al. (2013) which implies that crop intensification project has contributed to the livelihoods of farmers in different settings. In an interview with one of the exemplary maize farmers in Munyaga Sector, he stated that: Before joining crop intensification project activities. I was a motor taxi driver and to make food for my four children it was difficult. I later realized that I had to quit driving and started farming my land that I bought when I was a motor taxi driver. I started using organic and inorganic fertilizers to increase the productivity of my land. After, the first harvest I wanted to quit farming because the earning from farming was still low but later as I persisted, I started seeing the livelihood of my household has changed for the better and food at home was enough compared to the time that I had to buy legumes even if I had land. Today, I have improved my livelihood compared to the time I was still driving and I am now among the exemplary farmers in the whole of Rwamagana District.

\subsection{The effect of crop intensification project activities on improved household income of maize farmers in Munyaga Sector, Rwanda}

Table 4.2: Improvement made from household income after joining CIP activities

\begin{tabular}{lllllllll}
$\begin{array}{l}\text { Improvement after joining CIP } \\
\text { activites }\end{array}$ & & 4 & 3 & 2 & 1 & & Mean & Std. \\
\cline { 1 - 5 } $\begin{array}{l}\text { Food security at home } \\
\text { Paying household expenses }\end{array}$ & $0(0.0 \%)$ & $3(3.0 \%)$ & $10(10.1 \%)$ & $23(23.2 \%)$ & $63(63.6 \%)$ & 1.525 & .799 \\
Covering medical charges & $0(0.0 \%)$ & $10(10.1 \%)$ & $14(14.1 \%)$ & $15(15.2 \%)$ & $60(60.6 \%)$ & 1.737 & 1.045 \\
Paying school fees of children & $0(0.0 \%)$ & $16(16.2 \%)$ & $11(11.1 \%)$ & $12(12.1 \%)$ & $60(60.6 \%)$ & 1.828 & 1.160 \\
$\begin{array}{l}\text { Paying family credits and debts } \\
\text { Total mean }\end{array}$ & $0(0.0 \%)$ & $0(0.0 \%)$ & $0(0.0 \%)$ & $10(10.1 \%)$ & $89(89.9 \%)$ & 1.101 & .302 \\
\hline
\end{tabular}

Source: Primary Data, 2021

The findings in Table 4.2 are based on Likert scale results of 5 points where 1 is very satisfied, 2 satisfied, 3 not sure, 4 dissatisfied and 5 very dissatisfied. The results reveal that $89(89.9 \%)$ of respondents are very satisfied on improvement made in paying family credits and debts from household income, 69 (69.7\%) of respondents are very satisfied on improvement made in covering households expenses from household income, $63(63.6 \%)$ of respondents are very satisfied with improvement made on food security at home from household income after joining crop intensification project, 60 $(60.6 \%)$ of respondents are very satisfied with improvement made on paying school fees of children from household income after joining CIP, 60 (60.6) of respondents are very satisfied with improvement made on paying medical charges after joining CIP. The results have also indicated that the general mean is 1.549 which tends towards very satisfied with improvement made from household income after joining CIP in Munyaga Sector in Rwamagana of Rwanda.

The results of the study indicate that crop intensification project activities have contributed to the satisfaction of maize farmers due to improvement made from household income in Munyaga Sector. These results are supported by the findings of Berg et al., (2013) who stated that all the farmers who were satisfied with all improved practices of crop intensification and agricultural management which has increased the livelihood of many households.

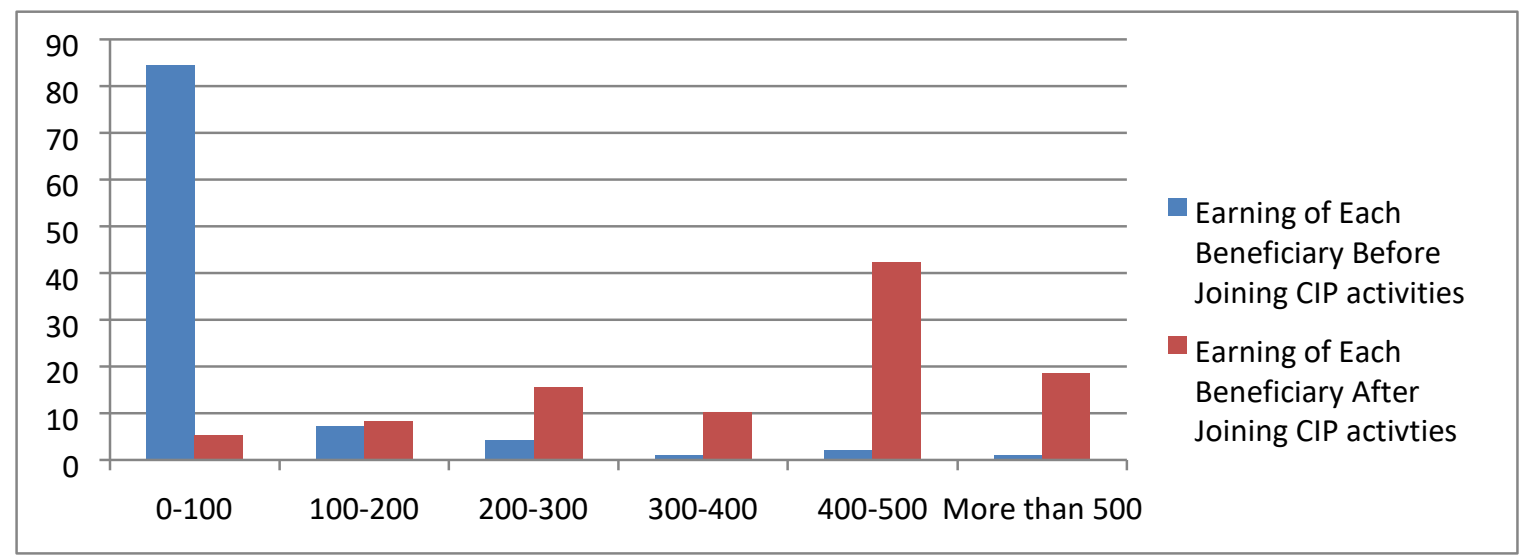

Figure 4. 1: Earning (in Thousands) of each maize farmer before and after joining crop intensification

\section{Source: Primary Data, 2021} project activities

The figure 4.1 demonstrates that $84(84.3 \%)$ of respondents before joining crop intensification project activities earned from 0 to $100000 \mathrm{Rwf}$ whereas only $5(5.1 \%)$ of respondents earned them after joining crop intensification project activities. The results also indicate that those who earned between 100000 to 200000 have only $1 \%(7.2-8.2 \%)$ between before and after joining crop intensification project activities. The results have also indicated that $4(4.1 \%)$ of respondents 
before joining crop intensification project activities earned from 200000 to 300000 Rwf whereas 16 (16.6\%) of respondents earned them after joining crop intensification project activities. The results have also revealed that 1 (1.0\%) of respondents before joining crop intensification project activities earned from 300000 to 400000 Rwf to maize farmers, whereas $10(10.3 \%)$ of respondents earned them after joining crop intensification project activities.

The results also show that $2(2.1 \%)$ of respondents before joining crop intensification project activities got from 400000 to $500000 \mathrm{Rwf}$ to maize farmers, whereas after joining crop intensification project activities, $41(42.3 \%)$ of respondents earned them after joining crop intensification project activities. The results have also indicated that $1(1.0 \%)$ of respondents before joining crop intensification project activities earned more than 500000 Rwf whereas, 18 (18.6\%) of respondents earned them after joining crop intensification project activities. Hence, this indicates that a big number of respondents before joining crop intensification project activities earned from 0 to 100000 Rwf whereas after joining crop intensification project activities they earned from 400000 to 500000 Rwf in Munyaga sector in Rwamagana District, Rwanda.

4.3 The relationship between crop intensification project activities and improved health of maize farmers in Munyaga Sector, Rwanda

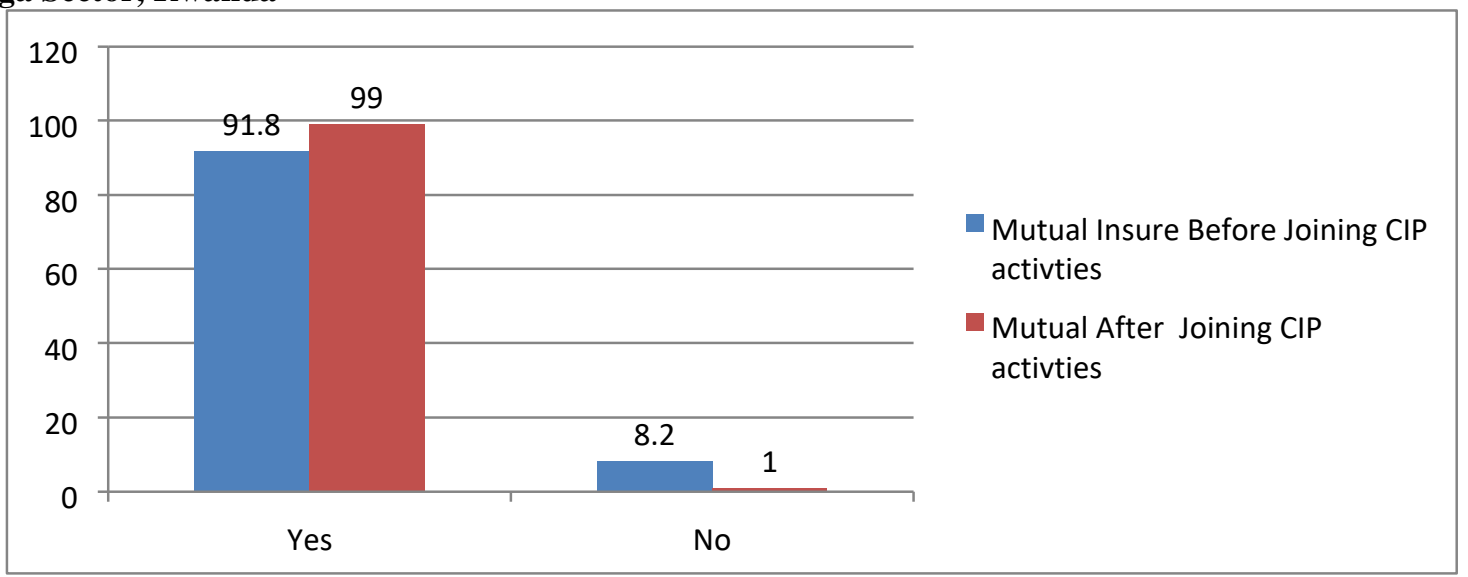

Figure 4. 2: Mutual Medical Insurance before and after joining CIP activities

Source: Primary Data, 20121

The Figure 4.2 shows that $91(91.8 \%)$ respondents accepted that they had mutual health insurance before joining CIP activities, $8(8.2 \%)$ of respondents accepted that they didn't have mutual health insurance before joining CIP activities. $98(99.0 \%)$ of respondents accepted that they got mutual health insurance after joining CIP activities, 1 (1.0\%) of respondents accepted that they didn't get mutual health insurance after joining CIP activities. Thus, implies that a big number of maize farmers had mutual health insurance before and joining CIP activities and it justifies the improvement of health among maize farmers in Rwamagana District, Rwanda.

In an interview with one of the exemplary maize farmers in Munyaga Sector of Rwamagana District, she stated that: $I$ also volunteer as a community health worker for a period of 5 years. Since, I joined crop intensification project, I started realizing that most of the people who pay for community health insurance fees at first are the people that we work together in crop intensification project activities compared to other groups of the people in our community. Thus, implies one way or the other they might be aware of the role of mutual health insurance or their livelihood has improved and affected how they think about their health which gears them to pay the community health insurance fees at first.

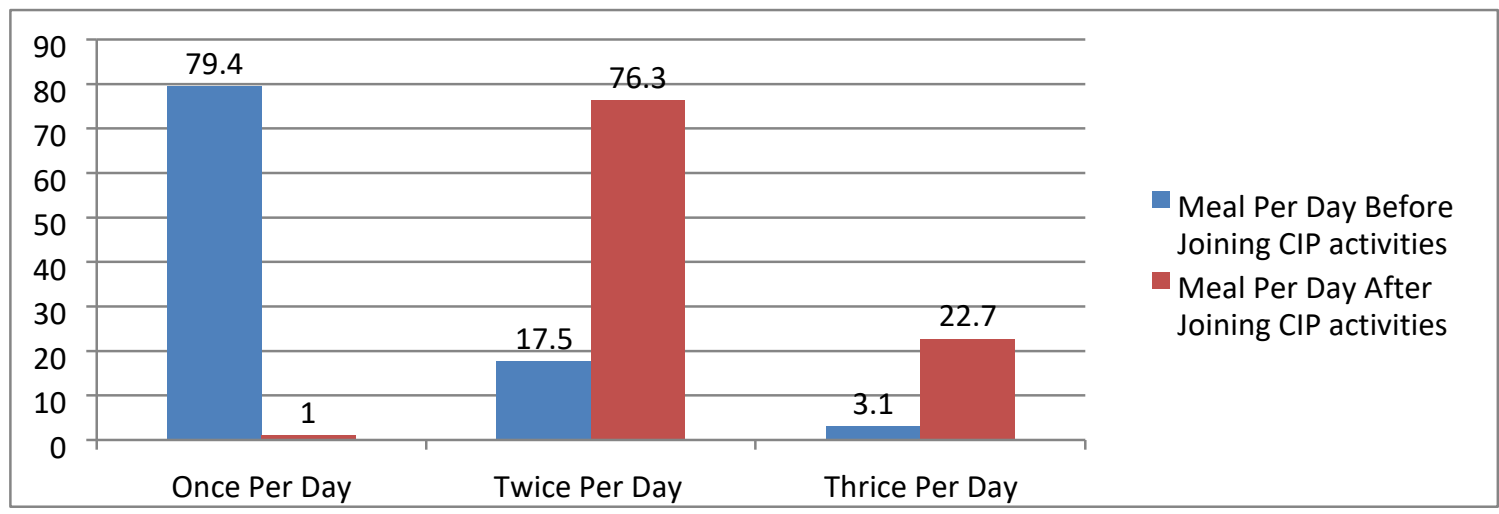

Figure 4. 3: Number of Meal per Day before and after joining crop intensification project activities Source: Primary Data, 2021

Results in Figure 4.3 have proved that 79 (79.8\%) respondents got one meal per day before joining crop intensification project activities while only $1(1.0 \%)$ of respondents get one meal per day after joining CIP activities. The results also 
show that 17 (17.5\%) of respondents got two meals per day before joining crop intensification project activities whereas $74(76.3 \%)$ of respondents get two meals per day after joining crop intensification project activities. The results have also revealed that $3(3.1 \%)$ of respondents got three meals per day before joining crop intensification project activities while after joining crop intensification project activities the people who get 3 meal per day increased to $22(22.2 \%)$ of respondents. Thus, it shows that a big number of maize farmers had to get one meal per day 79 (79.4\%). Whereas, the number of respondents who get two meals per day after joining crop intensification project activities have increase to 77 (76.3\%) in Rwamagana District, Rwanda.

Table 4.3: Descriptive statistics on the assessment of livelihood improvement of maize farmers in Munya Sector in Rwamagana

\begin{tabular}{lccccccc}
\hline $\begin{array}{l}\text { Livelihood improvement } \\
\text { assessment }\end{array}$ & 5 & 4 & 3 & 2 & 1 & Mean & Std. \\
\hline $\begin{array}{l}\text { Extension services affects } \\
\text { improved health }\end{array}$ & $5(5.1 \%)$ & $8(8.1 \%)$ & $9(9.1 \%)$ & $5(5.1 \%)$ & $72(72.7 \%)$ & 1.676 & 1.227 \\
$\begin{array}{l}\text { Increased land cultivation affects } \\
\text { improved household income }\end{array}$ & $3(3.0 \%)$ & $9(9.1 \%)$ & $12(12.1 \%)$ & $7(7.1 \%)$ & $68(68.7 \%)$ & 1.707 & 1.171 \\
$\begin{array}{l}\text { Increased land cultivation affects } \\
\text { improved household income }\end{array}$ & $9(9.1 \%)$ & $13(13.1 \%)$ & $6(6.1 \%)$ & $8(6.8 \%)$ & $68(68.7 \%)$ & 1.909 & 1.450 \\
General mean & & & & & & 1.764 \\
\hline
\end{tabular}

Source: Primary Data, 2021

The findings in Table 4.3 show that $72(72.7 \%)$ of respondents strongly agreed that extension services affect improved health. The $68(68.7 \%)$ of respondents strongly agreed that increased land cultivation affects improved household income, $68(68.7 \%)$ of respondents strongly agreed that increased land cultivation affects improved household income. The results have also indicated that the general mean is 1.764 which tends towards strongly agreed that predictors of crop intensification project activities affect livelihood improvement in Munyaga Sector of Rwamagana District of Rwanda. The findings of the study show that most of the maize farmers have bought assets to improve their livelihood from the amount earned from crop intensification project activities. The results are supported by the findings of Collier and Dercon (2014) who asserted that crop intensification has potentials to ensure that the Africans can meet the current and projected societal food needs and meet other household's demands to enhance continuing growth and change at the basic economics of smallholder farmers.

Table 4.4: Correlation analysis between predictors of CIP activities and livelihood improvement of farmers' households in Munyaga Sector of Rwamagana District in Rwanda

\begin{tabular}{|c|c|c|c|c|}
\hline & & $\begin{array}{l}\text { Improved } \\
\text { income }\end{array}$ & $\begin{array}{c}\text { household Increased diet and } \\
\text { security }\end{array}$ & $\begin{array}{c}\text { food Improved } \\
\text { health }\end{array}$ \\
\hline \multirow{3}{*}{$\begin{array}{l}\text { Extension } \\
\text { delivery }\end{array}$} & $\begin{array}{l}\text { Pearson } \\
\text { Correlation }\end{array}$ & $.574^{* *}$ & $.514^{* 4}$ & $.702^{* *}$ \\
\hline & ${ }^{\text {service }}$ Sig. (2-tailed) & .000 & .000 & .000 \\
\hline & $\mathrm{N}$ & 99 & 99 & 99 \\
\hline \multirow{3}{*}{$\begin{array}{l}\text { Increased } \\
\text { cultivation }\end{array}$} & $\begin{array}{l}\text { Pearson } \\
\text { Correlation }\end{array}$ & $.716^{* *}$ & $.479^{* *}$ & $.730^{* *}$ \\
\hline & Sig. (2-tailed) & .000 & .000 & .000 \\
\hline & $\mathrm{N}$ & 99 & 99 & 99 \\
\hline \multirow{3}{*}{$\begin{array}{l}\text { Increased } \\
\text { yield }\end{array}$} & $\begin{array}{l}\text { Pearson } \\
\text { Correlation }\end{array}$ & $.936^{* *}$ & $.518^{* *}$ & $.655^{* *}$ \\
\hline & seeds and Sig. (2-tailed) & .000 & .000 & .000 \\
\hline & $\mathrm{N}$ & 99 & 99 & 99 \\
\hline
\end{tabular}

**. Correlation is significant at the level of 0.01 (2-tailed).

Source: Primary Data, 2021

The results in Table 4.4 proves that there is a relationship between extension service delivery and improved household income $(\mathrm{p}=.574$ and $\mathrm{sig}=.000)$, between extension service delivery and increased diet and food security $(\mathrm{p}=.514$ and sig=.000), between extension service delivery and improved health $(\mathrm{p}=.702$ and sig=.000), between increased land cultivation and improved household income $(\mathrm{p}=.716$ and sig=.000) and between increased land cultivation and increased diet and food security $(\mathrm{p}=.479$ and $\mathrm{sig}=.000)$.

The same results of the Table 4.4 continue to prove a relationship between increased land cultivation and improved health $(\mathrm{p}=.730$ and sig=.000) between increased seeds and yield and improved household income $(\mathrm{p}=.936$ and sig=.000) between increased seeds and yield and increased diet and food security $(\mathrm{p}=.518$ and sig=.000) between increased seeds and yield and improved health $(\mathrm{p}=.655$ and $\mathrm{sig}=.000)$ because all the calculated $\mathrm{p}$-values are less than 0.01 level of significance. 
This implies that there is a relationship between predictors of crop intensification project activities and livelihood improvement of maize farmers in Munyaga Sector of Rwamagana District in Rwanda.

The results from the study of Tittonell \& Giller, (2013) support the findings of this research which prove that there is a relationship between crop intensification project activities and livelihood improvement of maize farmers in Munyaga Sector because their study has proved that crop intensification efforts through agricultural management and improved practices has a remarkable positive relationship with improved livelihoods of major cereal farmers.

Table 4.5: Model Summary of CIP activities and improved household income as livelihoods of Maize farmers in Munyaga Sector in Rwanda

\begin{tabular}{lllll}
\hline Model & R & R Square & Adjusted R Square & Std. Error of the Estimate \\
\hline $.938^{\mathrm{a}}$ & .879 & .875 & .44656 \\
\hline
\end{tabular}

a. Predictors: (Constant), Increased seeds and yield, Extension service delivery, Increased land cultivation Source: Primary data, 2021

The findings in Table 4.5 indicate that the $\mathrm{R}$ coefficient.938 proves that crop intensification project activities have a positive relationship with extension of services delivery. The determination coefficient $.879 \mathrm{R}$ square also reveals that crop intensification project activities explains $87.9 \%$ the progress variability in extension of services delivery. Thus, it implies that predictors of crop intensification project activities such as improved seeds, yields and increased land of cultivation affect the progress of improved household income by $87.9 \%$ in CIP Munyaga Sector of Rwamagana District in Rwanda.

Table 4.6: Analysis of Variance (ANOVA) of CIP activities and improved household income as livelihoods of Maize farmers in Munyaga Sector in Rwanda

\begin{tabular}{llllll}
\hline Model & Sum of squares & Df & Mean Square & F & Sig. \\
\hline Regression & 137.561 & 3 & 45.854 & 229.945 & $.000^{\mathrm{b}}$ \\
Residual & 18.944 & 95 & .199 & & \\
Total & 156.505 & 98 & & & \\
\hline
\end{tabular}

a. Dependent Variable: Improved household income

b. Predictors: (Constant), Increased seeds and yield, Extension service delivery, Increased land cultivation Source: Primary Data, 2021

The Table 4.6 revealed that crop intensification project activities has a positive and significant relationship with improved household income since the calculation made on p-values 0.00 are less than 0.05 level of significance. The model of the statistics of crop intensification project activities and improved household income has a relationship which is significant. The findings of Matsumoto \& Yamano (2011) have shown that the application of nitrogen has increase the yield of the crop intensification as a complementary technology and these have shown a remarkable and significant increase household income. Thus, his results support the findings of this study which asserts that crop intensification project activities have a significant impact on improved household income.

Table 4.7: Coefficients of CIP activities and improved household income as livelihoods of Maize farmers in Munyaga Sector in Rwanda

\begin{tabular}{llllll}
\hline Model & \multicolumn{2}{l}{$\begin{array}{l}\text { Unstandardized } \\
\text { Coefficients } \\
\text { B }\end{array}$} & $\begin{array}{l}\text { Standardized } \\
\text { Coefficients } \\
\end{array}$ & $\begin{array}{l}\text { Std. Error } \\
\text { Beta }\end{array}$ & Sig. \\
\hline (Constant) & .039 & .085 & & .461 & .646 \\
Extension service delivery & .062 & .047 & .058 & 1.309 & .002 \\
& & & & & \\
Increased land cultivation & .052 & .065 & .043 & .802 & .004 \\
Increased seeds and yield & .906 & .057 & .871 & 15.762 & .000 \\
\hline
\end{tabular}

a. Dependent Variable: Improved household income

Source: Primary Data, 2021

The Table 4.7 revealed a positive effect of crop intensification project activities to improved household income due to the positive regression coefficients which at the same time turned the regression model of $Y=B_{0}+\beta_{1} X_{1}+\beta_{2} X_{2}+\beta_{3} X_{3}+\varepsilon$ which became $\mathrm{Y}=.039+.062 \times 1+052 \times 2+.906 \times 3$ to prove that crop intensification project activities and improved household income has positively significant relationship among the Maize Farmers in Munyaga Sector of Rwamagana in Rwanda. The first objective of establishing the relationship between extension of service delivery and improved household income $(b=.062$ and $p=.002)$ shown a relationship which is positive and significant. The second objective of increased land of cultivation and improved household income $(\mathrm{b}=.058$ and sig=.004) proving a positive and significant relationship. The 
third objective of improved seeds and yields and improved household income $(\mathrm{b}=.906$ and $\mathrm{p}=.000)$ proving a relationship which is positive and significant. Thus, the statistics proves a significantly positive relationship between crop intensification project activities and improved household income in Munyaga Sector.

The findings from the study of Diagne et al, (2013) have shown that crop intensification has a significant relationship with the productivity gain which increases the income of households. Thus, the study supports this result of the study which asserts that crop intensification project activities have a positively significant relationship with improved household income in Munyaga Sector.

Table 4.8: Model Summary of CIP activities and increased diet and food security as livelihoods of Maize farmers in Munyaga Sector in Rwanda

\begin{tabular}{lllll}
\hline Model & R & R Square & Adjusted R Square & Std. Error of the Estimate \\
\hline 1 & $.590^{\mathrm{a}}$ & .348 & .327 & .89312 \\
\hline
\end{tabular}

a. Predictors (Constant), Increased seeds and yield, Extension service delivery, Increased land cultivation Source: Primary Data, 2021

The results in Table 4.8 indicate that the $\mathrm{R}$ coefficient .590 explains that crop intensification project activities have a positive relationship with increased diet and food security. The coefficient of determination $348 \mathrm{R}$ square also reveals that crop intensification project activities explains $34.8 \%$ the progress variability in increased diet and food security. Thus, it implies that predictors of crop intensification project activities as increased land of cultivation, improved seeds and yields and extension service delivery affect the progress of increased diet and food security by $34.8 .0 \%$ in CIP Munyaga Sector of Rwamagana District in Rwanda.

The study of Pretty et al. (2011) supports the results of this research as he stipulated that crop intensification show a very remarkable increase of food production on the same amount of land which at the same period favors the coexistence of other natural environmental resources.

Table 4.9: Analysis of Variance (ANOVA) of CIP activities and increased diet and food security as livelihoods of Maize farmers in Munyaga Sector in Rwanda

\begin{tabular}{llllll}
\hline Model & Sum of squares & Df & Mean square & F & Sig. \\
\hline Regression & 40.404 & 3 & 13.468 & 16.884 & $.000^{\text {b }}$ \\
Residual & 75.778 & 95 & .798 & & \\
Total & 116.182 & 98 & & & \\
\hline
\end{tabular}

a. Dependent Variable: Increased diet and food security

b. Predictors: (Constant), Increased seeds and yield, Extension service delivery, Increased land cultivation Source: Primary data, 2021

The Table 4.9 results show that intensification of crop project activities and increase diet and food security has a positively significant relationship because the calculation made on p-value 0.00 is less than 0.05 level of significance. Hence, the model of statistics proves that crop intensification project activities and increases diet and food security has a significantly positive relationship in Munyaga Sector, Rwamagana District of Rwanda.

Table 4.10: Coefficients of CIP activities and increased diet and food security as livelihoods of Maize farmers in Munyaga Sector in Rwanda

\begin{tabular}{|c|c|c|c|c|c|}
\hline \multirow[t]{2}{*}{ Model } & \multicolumn{2}{|c|}{$\begin{array}{l}\text { Unstandardized Coef } \\
\text { B }\end{array}$} & $\begin{array}{l}\text { Standardized } \\
\text { Coefficients Beta }\end{array}$ & $\mathrm{T}$ & \multirow[t]{2}{*}{ Sig. } \\
\hline & & Std. & & & \\
\hline (Constant) & .561 & .170 & & 3.297 & .001 \\
\hline Extension service delivery & $\begin{array}{l}.277 \\
.137\end{array}$ & $\begin{array}{l}.094 \\
.130\end{array}$ & $\begin{array}{l}.301 \\
.133\end{array}$ & $\begin{array}{l}2.926 \\
1.057\end{array}$ & $\begin{array}{l}.004 \\
.003\end{array}$ \\
\hline $\begin{array}{l}\text { Increased land cultivation } \\
\text { Increased seeds and yield }\end{array}$ & .224 & .115 & .250 & 1.950 & .004 \\
\hline
\end{tabular}

a. Dependent Variable: Increased diet and food security

Source: Primary data, 2021

The Table 4.10 stipulate that crop intensification project activities has a positive effect on the increase diet and food security due to the fact that the calculations made of the $\mathrm{p}$-values are less than 0.05 level of significance and the regression coefficients are positive. Thus, the regression equation $Y=\beta_{0}+\beta_{1} X_{1}+\beta_{2} X_{2}+\beta_{3} X_{3}+\varepsilon$ turns into $\mathrm{Y}=.561+.277 \times 1+.137 \times 2+.224 \times 3$, this regression equation reveals that there is a positive significance between predictors of crop intensification project activities and Increased diet and food security of Maize Farmers in Munyaga Sector of Rwamagana in Rwanda.

The first objective of establishing the relationship between extension of service delivery and increased diet and food security $(b=.227$ and $p=.004)$ proving a significantly positive relationship. The second objective is of increased land cultivation and increased diet and food security $(b=.137$ and sig=.003) proving a positively significant relationship 
between the two. The third objective is of improved seeds and yields and increase diet and food security $(b=.224$ and $\mathrm{p}=.004)$ with a relationship which significantly positive. Therefore, crop intensification project activities and increased diet and food security has a positive and significant relationship in CIP of Munyaga Sector, Rwamagana District of Rwanda.

The study of Knox et al., (2012) supports the results of this study which states that crop intensification project activities has a significant relationship to the increased diet and food security of maize farmers in Munyaga Sector. They results have indicated that despite the struggle of the farmers to adopt to crop intensification the projections indicates that the annual growth in crop and livestock productivity keep multiplying. They projected that by the 2050 crop intensification will incase ensure food security.

Table 4.11: Model Summary of CIP activities and improved health as livelihoods of Maize farmers in Munyaga Sector in Rwanda

\begin{tabular}{lllll}
\hline Model & R & R Square & Adjusted R Square & Std. Error of the Estimate \\
\hline $.820^{\mathrm{a}}$ & .672 & .662 & .68592 \\
\hline
\end{tabular}

a. Predictors: (Constant), Increased seeds and yield, Extension service delivery, Increased land cultivation Source: Primary data, 2021

The Table 4.11 shows the $\mathrm{R}$ coefficient of .820 which proves a positively significant relationship between crop intensification project activities and improved health. The determination coefficients of .672 $\mathrm{R}$ square shows that improved heath progress can be affected by crop intensification project activities on the rate of $67.2 \%$ in Maize farmers of Munyaga Sector, Rwamanaga District of Rwanda.

The findings of Ouya et al., (2020) stated that crop intensification project seeks to support a $60 \%$ increase in farm level yield in 2.5 million households by 2013 as per projection, a long minimum increase in household income of $44 \%$ in the same number of households. Thus, these results support the findings of this study because crop intensification project activities improved health as part of livelihood by $67.2 \%$ in the maize farmers in Munyaga Sector.

Table 4.12: Analysis of Variance (ANOVA) of CIP activities and improved health as livelihoods of Maize farmers in Manyata Sector in Rwanda

\begin{tabular}{llllll}
\hline Model & Sum of Squares & Df & Mean Square & F & Sig. \\
\hline Regression & 91.627 & 3 & 30.542 & 64.916 & $.000^{\mathrm{b}}$ \\
Residual & 44.697 & 95 & .470 & & \\
Total & 136.323 & 98 & & \\
\hline
\end{tabular}

a. Dependent Variable: Improved health

b. Predictors: (Constant), Increased seeds and yield, Extension service delivery, Increased land cultivation Source: Primary data, 2021

The Table 4.12 shows that crop intensification project activities and improved health calculations made on the $\mathrm{p}$-value 0.00 is less than 0.05 level of significance which proving a positively significant relationship between the two. Thus, the statistics of this model prove a positively significant relationship between the predictors of crop intensification project activities and improved health in Munyaga Sector, Rwamagana District of Rwanda.

Table 4.13: Coefficients of CIP activities and improved health as livelihoods of Maize farmers in Munyaga Sector in Rwanda

\begin{tabular}{|c|c|c|c|c|c|}
\hline \multirow[t]{2}{*}{ Model } & \multicolumn{2}{|c|}{ Unstandardized Coefficients } & Standardized Coefficients & $\bar{T}$ & Sig. \\
\hline & B & Std. Error & Beta & & \\
\hline (Constant) & .114 & .131 & & .875 & .384 \\
\hline Extension service delivery & .409 & .073 & .411 & 5.632 & .000 \\
\hline Increased land cultivation & .483 & .100 & .431 & 4.851 & .000 \\
\hline Increased seeds and vield & .102 & .088 & .105 & 1.156 & .001 \\
\hline
\end{tabular}

a. Dependent Variable: Improved health

Source: Primary data, 2021

The findings in table 4.13 proved a positive and significant effect of crop intensification project activities on improved health due to the fact that the calculations made of $\mathrm{p}$-values are less than 0.05 level of significance while the coefficients of regression are positive and making the regression model of $Y=\beta_{0}+\beta_{1} X_{1}+\beta_{2} X_{2}+\beta_{3} X_{3}+\varepsilon$ to turn into $\mathrm{Y}=.114+.409 \mathrm{X}_{1}+483 \mathrm{X}_{2}+.102 \mathrm{X}_{3}$, this regression equation reveals that there is a positive significance between predictors of crop intensification project activities and Improved health in Munyaga Sector of Rwamagana District in Rwanda.

The first objective of establishing the relationship between extension of service delivery and improved health has $(b=.114$ and $\mathrm{p}=.000$ ) proving a significantly positive relationship. The second objective is of increased land of cultivation and improved health $(b=.409$ and sig=.000) proving a positively significant relationship. The third objective is of improved seeds and yields and improved health $(\mathrm{b}=.102$ and sig=.001) proving a positive and significant relationship between the two. Thus, crop intensification project activities and improved health has a positive and significant relationship among the farmers in Munyaga Sector of Rwamagana District in Rwanda. The study has shown that crop intensification project 
activities and livelihoods' improvement have a positive and significant relationship. Thus, these results are supported by the research of Burke et al., (2017) who stipulated that crop intensification has improved the effectiveness of complimented mineral fertilizer and nonmineral nutrients which has shown a significant improvement on the productivity of land produce to enhance the livelihoods of farmers.

Table 4.14: Constraints of farmers face during implementation of maize intensification

\begin{tabular}{llllllll}
\hline Constraints & 5 & 4 & 3 & 2 & 1 & Mean & Std. \\
\hline Unpredicted market price & $8(8.1 \%)$ & $7(7.1 \%)$ & $10(10.1 \%)$ & $21(21.2 \%)$ & $53(53.5 \%)$ & 1.949 & 1.288 \\
Low production & $3(3.0 \%)$ & $4(4.0 \%)$ & $5(5.1 \%)$ & $7(7.1 \%)$ & $80(80.8 \%)$ & 1.414 & .9794 \\
Lack of proper storage & $3(3.0 \%)$ & $3(3.0 \%)$ & $4(4.0 \%)$ & $7(7.1 \%)$ & $82(82.8 \%)$ & 1.363 & .9308 \\
Floods & $5(5.1 \%)$ & $4(4.0 \%)$ & $4(4.0 \%)$ & $8(8.1 \%)$ & $82(82.8 \%)$ & 1.323 & .8185 \\
Heavy rainfall & $5(5.1 \%)$ & $4(4.0 \%)$ & $4(4.0 \%)$ & $9(9.1 \%)$ & $77(77.8 \%)$ & 1.494 & 1.091 \\
Long dry season & $3(3.0 \%)$ & $6(6.1 \%)$ & $5(5.1 \%)$ & $9(9.1 \%)$ & $76(76.8 \%)$ & 1.494 & 1.043 \\
General mean & & & & & & 1.506 & \\
\hline
\end{tabular}

Source: Primary data, 2021

The findings in Table 4.14 reveals that $82(82.8 \%)$ strongly agreed that floods are the challenging constraints that farmers face during implementation of maize intensification project, $82(82.8 \%)$ strongly agreed that lack of proper storage is the challenging constraints that farmers face during implementation of maize intensification project, 80 (80.8\%) strongly agreed that low production is the challenging constraints that farmers face during implementation of maize intensification project, $77(77.8 \%)$ strongly agreed that heavy rainfall is the challenging constraints that farmers face during implementation of maize intensification project, 76 (76.8\%) strongly agreed that long dry season is the challenging constraints that farmers face during implementation of maize intensification project and $53(53.5 \%)$ strongly agreed that unpredicted market price is the challenging constraints that farmers face during implementation of maize intensification project. The results have also indicated that the general mean is 1.506 which tends towards strongly agreed that number of challenges face farmers that need solutions in order to implement maize intensification project efficiently and enhance livelihood improvement in households of farmers in Munyaga Sector of Rwamagana in Rwanda.

\subsection{Conclusion}

In conclusion, the results of the first objective proved that crop intensification project activities conducted by Maize farmers to increase diet and food security in Munyaga Sector, Rwanda. To compare the results of this research with that of Townsend et al., (2013), who stated that sustainable intensification of agricultural yield has become predominant theme in the development agendas and it has helped to improve the livelihood of rural households. Thus, the results are supported by the results of Townsend et al. (2013) which implies that crop intensification project has contributed to the livelihoods of farmers in different settings.

The results of the second objective have proven that crop intensification project activities have improved the level of satisfaction of the farmers due to increased household income in Munyaga Sector. These results are supported by the findings of Berg et al., (2013) who stated that all the farmers who were satisfied with all improved practices of crop intensification and agricultural management which has increased the income of many households.

The results of the third objective is supported by the results of the study of Tittonell \& Giller, (2013) support the finding s of this research which prove that there is a relationship between crop intensification project activities and improved health of maize farmers in Munyaga Sector because their study has proved that crop intensification efforts through agricultural management and improved practices has a remarkable positive relationship with improved well-being and health of cereal farmers.

\subsection{Acknowledgement}

As a matter of first importance, I thank the Almighty God on the abundant protections, guidance and blessings during my field of work and studies at large. Also feel highly indebted and full of gratitude to the staff of Mount Kenya University especially to the lecturers of Development Studies Department. Deeply from my heart, I here want to acknowledge the beloved parents, brothers and sisters, aunts and uncles and relatives for their great financial support provided to realize this study and any person who directly or indirectly contributed to the success of my work. My thanks also go to the local district leaders and Munyaga farmers who kindly answered my questions that have provided information for this job, here is my sincere acknowledgment. My great thanks go to the members of Nkungu Secondary School as well as my colleagues for various assistances they have offered throughout my studies and the classmates for their constructive matters during my studies at Mount Kenya University.

\section{References}

[1].Burke, W. J., Jayne, T., \& Black, J. R. (2017). Factors explaining the low and variable profitability of fertilizer application to maize in Zambia. Journal of Agricultural Economics, 48(1), 115-126.

[2].Cantore, N. (2011). The Crop Intensification Program in Rwanda: a sustainability analysis. Overseas Development Institute, Westminster Bridge Road, London, SE1 7JD.

[3].Collier, P. \& Dercon, S. (2014). African Agriculture in 50 Years: Smallholders in a Rapidly Changing World? Journal of World Development 6(3)92-101. DOI: 10.1016/j.worlddev.2013.10.001 
[4].Diagne, A., Alia, D., Amovin-Assagba, E., Wopereis, M. S. C., \& Saito, K. (2013). Farmer perceptions of the biophysical constraints to rice production in sub-Saharan Africa, and potential impact of research. In M. C. S. Wopereis, D. E. Johnson, N. Ahmadi, E. Tollens, \& A. Jalloh (Eds.), Realizing Africa's rice promise (pp. 46-68). Wallingford: $\mathrm{CAB}$ International.

[5].Food and Agriculture Organisation, International Fund for Agriculture Development, United Nations Children's Fund, World Food Programme \& World Health Organisation. (2021). The State of Food Security and Nutrition in the World 2021. Transforming food systems for food security, improved nutrition and affordable healthy diets for all. Rome, FAO. https://doi.org/10.4060/cb4474en

[6].Kabandana, A. (2016). Challenges associated with the land law, policy and crop intensification program (CIP) in Rwanda, Academia. Internet Resource: http://www.academia.edu/12261810 (Accessed, February 21, 2021).

[7].Knox, J., T., Hess, A., \& Wheeler, T. (2012). Climate change impacts on crop productivity in Africa and South Asia. Environmental Research Journal, 7 (3), 40-52, doi:10.1088/1748-9326/7/3/034032

[8].Matsumoto, T. \& Yamano, T. (2011). Optimal Fertilizer Use on Maize Production in East Africa. In Emerging Development of Agriculture in East Africa: Markets, Soil, and Innovations, ed. T. Yamano, K. Otsuka, and F. Place. The Netherlands: Springer.

[9].MINAGRI. (2011). Sustainable Crop Intensification in Rwanda, shifting focus from producing enough to producing surplus.Ministry of Agriculture and Animal Resources. Kigali, Rwanda.

[10]. Ouya, F., Ingasia, O., \& Kariuki, M.I. (2020). Effects of agricultural intensification practices on smallholder farmers' livelihood outcomes in Kenyan hotspots of Climate Change. East African Journal of Science Technology and Innovation 2(1), 21-35. DOI: 10.37425/eajsti.v2i1.110

[11]. Pretty, J., Toulmin, C., \& Williams, S. (2011). Sustainable intensification in African agriculture. International Journal of Agricultural Sustainability, 9(1), 5-24. doi: 10.3763/ijas.2010.0583

[12]. Sheahan, M. \& Barrett, C. B. (2017). Ten striking facts about agricultural input use in Sub-Saharan Africa. Journal of Food Policy, Elsevier, 67(C), 12-25. DOI: 10.1016/j.foodpol.2016.09.01

[13]. Sommer, R., Bossio D., Desta L., Dimes J., Kihara J., Koala S., Mango N., Rodriguez D., Thierfelder C., Winowiecki L. (2013). Profitable and Sustainable Nutrient Management Systems for East and Southern African Smallholder Farming Systems - Challenges and Opportunities. https://repository.cimmyt.org/handle/10883/4035

[14]. Valbuena, D., Tui S.H.K., Erenstein O., Teufel N., Duncan A., Abdoulaye T., Swain B., Mekonnen K., Germaine I., Gérard B. (2015). Identifying determinants, pressures and trade- offs of crop residue use in mixed smallholder farms in Sub-Saharan Africa and South Asia. Journal of Agriculture Systems, 134 (3) 107-118. 